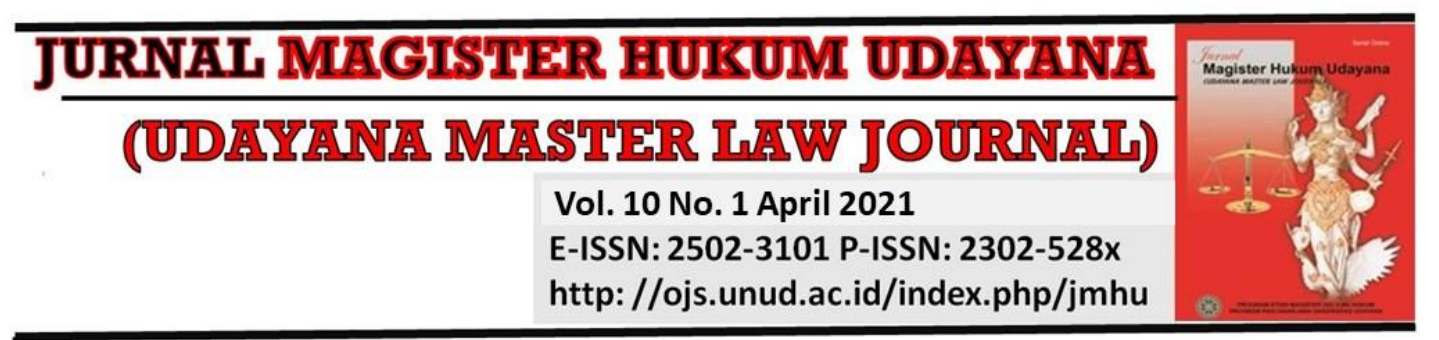

\title{
Urgensi Perlindungan Hukum Terhadap Jurnalis Perempuan Berspektif Kesetaraan Gender
}

\section{Dwi Pusparini ${ }^{1}$, Gede Made Swardhana ${ }^{2}$}

${ }^{1}$ Fakultas Hukum Universitas Udayana, E-mail: dwipusparini17@gmail.com

${ }^{2}$ Fakultas Hukum Universitas Udayana, E-mail: gmswar@yahoo.com

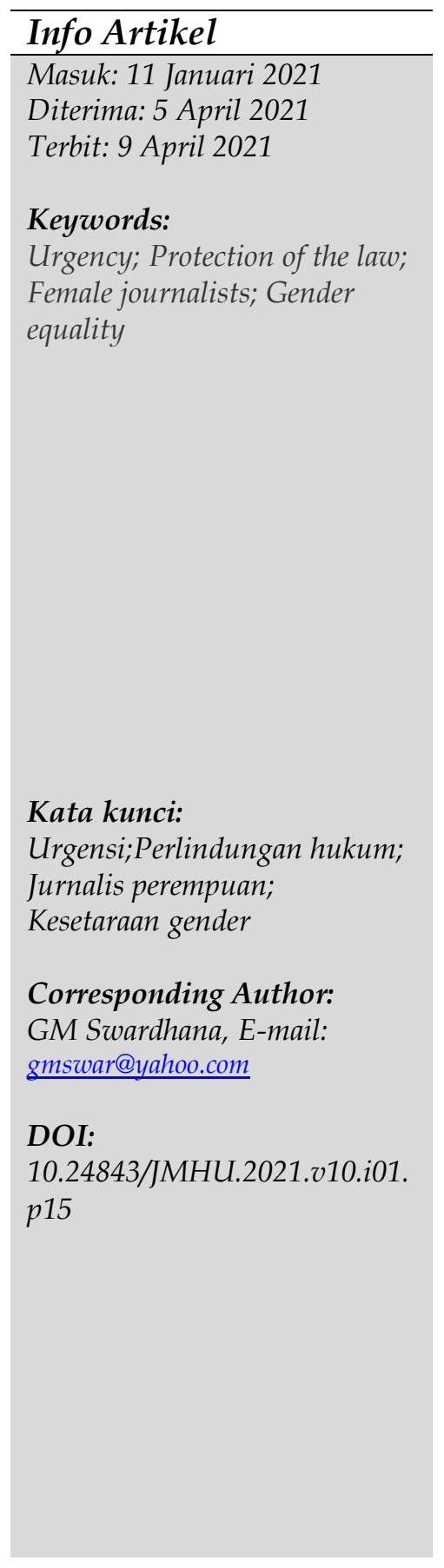

\begin{abstract}
The purpose of writing/research to answers to legal problems experienced by female journalists in a gender perspective and to know strategy of legal protection for female journalists in the future. This type of research is normative legal research. The type of approach used is the statutory and conceptual approach. The results of this study showed that the problem of gender in media is more or less related to the position of marginalization and subordination for women in various fields, among others, the lack of involvement for women in journalism activities, legitimacy regarding gender bias, economic and political interests that dominate, regulation in media that is insensitive about gender and the gap between conventional and gender sensitive journalism. Prevention of protracted gender inequality concerning women, especially against female journalists, it is necessary to have a legal reconstruction considering that women are citizens in the development of women's resources certainly have the same position as men in terms of their position, their rights and obligations so as to get equal opportunities in various fields.
\end{abstract}

Abstrak
Tujuan penulisan/penelitian adalah mengetahui jawaban
mengenai permasalahan hukum yang dialami oleh jurnalis
perempuan dalam perspektif gender dan mengetahui strategi
perlindungan hukum terhadap jurnalis perempuan dimasa yang
akan datang. Jenis penelitian ini adalah penelitian hukum
normatif. Jenis pendekatan yang digunakan yaitu pendekatan
perundang-undangan dan konseptual. Teknik pengumpulan data
yang digunakan adalah studi kepustakaan. Hasil penelitian ini
menunjukan bahwa Permasalahan berspektif gender pada media
menyangkut pada posisi marginalisasi dan subordinasi bagi
perempuan diberbagai bidang antara lain, sedikitnya keterlibatan
bagi perempuan pada aktivitas jurnalisme, legitimasi mengenai
bias gender, kepentingan ekonomi dan politik yang mendominasi,
regulasi pada media yang tidak sensitive mengenai gender serta
kesenjangan antara jurnalisme konvenssional serta sensitive
gender. Pencegahan ketimpangan gender yang berlarut-larut
mengenai perempuan khususnya terhadap jurnalis perempuan
maka perlu adanya rekonstruksi hukum mengingat perempuan
merupakan warga negara dalam pembangunan sumber daya
perempuan tentu mempunyai kedudukan sama terhadap laki-laki
dalam hal kedudukannya, hak-haknya serta kewajiban-


kewajibannya sehingga memperoleh kesempatan yang sama

dalam berbagai bidang.

\section{Pendahuluan}

Tatanan demokrasi Indonesia tidak terhindarkan dari peran pers yang memiliki peran yang sangat besar diberbagai aspek. Dalam pasal 28 UUDNRI tahun 1945 telah mengakui kebebasan dalam mengemukaan suatu pendapat yang memiliki arti untuk mewujudkan negara yang demokratis dan tetap berpijak pada hukum yang berlaku yang dalam hal ini secara tidak langsung megakomodir nilai kemerdekaan pers tersebut. Di luar negeri khususnya Amerika sedikitnya jumlah perempuan dalam aspek baik pengelolaan maupun kepemilikan media seperi penelitian oleh Byerly kurang dari enam persen perempuan dalam pengelolaan serta memiliki media baik televisi ataupun radio. ${ }^{1}$

Pentingnya pers tentu sangat penting bagi pembangunan sebuah negara yaitu memberikan gambaran serta berbagai informasi sehingga memberikan reaksi baik maupun buruk kepada masyarakat. Keberadaan pers tidak akan dapat dilepaskan dari peran seorang wartawan dalam hal pencari informasi yang ditayangkan lewat media social. Tidak sedikit wartawan saat bertugas dilapangan terkadang penuh resiko yang harus dihadapi baik di zona berbahaya sekalipun walaupun Pers telah diatur dalam UU No.40 Tahun 1999. Berdasar pada Pasal 1 angka 4 memberikan pengertian mengenai wartawan adalah orang yang teratur dalam pelaksaan kegiatan jurnalistik. Hiru R. Muhamad menyatakan bahwa UU Pers sebagai payung hukum dalam memberikan perlindungan bagi profesi jurnalistik tetap pada tanggung jawabnya yaitu memberikan informasi demi kepentingan publik. ${ }^{2}$ Pada Undang-Undang No. 11 tahun 2008 mengenai Informasi dan Transaksi Elektronik yang pada dasarnya menegaskan batasna-batasan etika dan mengantisipasi adanya pelanggaran-pelanggaran pada dunia maya ataupun social media yang juga harus ditaati oleh Pers khususnya jurnalis.

Dalam hal pembelaan kepentingan pers, maka dibentuknya Dewan Pers yang tentu masih tidak dapat berbuat banyak untuk pembelaan kepentingan pers dalam mencari keadilan. Kebebasan pers haruslah tetap mempunyai batasan-batasan yaitu tanggung jawab social serta professional sehingga berita yang di publikasikan tidak menimbulkan keresahan serta perpecahan di masyarakat seperti menyinggung suku, agama , ras dan antargolongan lainnya.

Peran media massa sangat penting dalam kehidupan masyarakat yaitu dalam hal sebagai sarana komunikasi. Pendapat MCluhan \& Quentin Fiore bahwa media dalam tiap zamannya menjadi esensi dalam kehidupan masyarakat tersebut. Dengan ini telah menunjukan media serta masyarakat adalah saling berkaitan serta mempunyai dampak dalah kehidupan masyarakat tersebut baik dalam arah positif maupun negative. ${ }^{3}$ Kehadiran media sangat memberikan pengaruh besar terhadap kehidupan masyarakat baik masyarakat kota hingga masyarakat desa. Menurut KBBI memberikan

${ }^{1}$ Carolyn M Byerly, "Behind the Scenes of Women's Broadcast Ownership," The Howard Journal of Communications 22, no. 1 (2011): 24-42.

2 Erman Anom, “Wajah Pers Indonesia 1999-2011," Jurnal Komunikasi: Malaysian Journal of Communication 27, no. 1 (2011).

${ }^{3}$ Sam Neill, “Books and Marshall McLuhan," The Library Quarterly 41, no. 4 (1971): 311-19. 
pengertian bahwa media massa merupakan salah satu sarana serta saluran yang bersifat resmi sebagai alat komunikasi dalam hal penyebaran berita dan pesan untuk masyarakat luas.

Media massa dalam kehidupan manusia sebagai sarana komunikasi sebagai pelopor dalam hal perubahan baik lingkungan publik, pendidikan, perekonomian yang dapat dijangkau secara luas. Dalam era perkembangan teknologi serta komunikasi, memberikan posisi terhadap media massa menjalankan era sebagai komunikator. Media massa yang memiliki peran yang signifikan bahwa media massa memiliki peran yang berpengaruh kepada masyarakat sehingga isi dari siaran tersebut dapat mempengaruhi realitas subjektif bagi pelaku interaksi social. Media massa dalam perannya sebagai agen of change yang berarti bahwa media tidak hanya mempengaruhi pengetahuan seseorang akan tetapi berpengaruh dalam hal keingintahuan.

Dibalik kemajuan dalam media massa tak terlepas dari peran jurnalis dalam memberikan informasi yang menarik baik pemberian informasi dari jurnalis laki-laki maupun perempuan. Perlu diketahui bahwa di Indonesia, jurnalis yang bergender laki-laki lebih banyak jika dibandingkan dengan jurnalis yang bergender perempuan, sehingga tidak dipungkiri menjadikan kondisi ketimpangan dalam profesi jurnalistik maupun media. Yang seharusnya dalam perpektif gender, hak yang diterima oleh jurnalis perempuan seharusnya sama dengan hak yang diterima oleh jurnalis laki- laki. Penelitian di Inggris dan Republik Irlandia, terlihat bahwa dalam pengambilan keputusan isu serta topic yang relevan bagi perempuan yang dianggap kurang penting dan redaksi cenderung pemberitaan yang layak adalah bernilai maskulin maka dapat dikatakan laki-laiki memberikan kendali yang besar dibandingkan perempuan. ${ }^{4}$

Banyak yang berspekulasi bahwa dunia jurnalistik adalah tempat untuk dunia laki-laki saja. Dimana dalam media khususnya televisi profesi presenter telah dianggap lebih impresif daripada jurnalis perempuan yang bertugas dilapangan. sehingga dianggap penting jika perlunya perbaikan dalam aturan-aturan kerja jurnalis di Indonesia. Tidak sedikit jurnalis perempuan yang berdampak pada permasalahan keadilan dan kesejahteraan serta kesetaraan gender yang disebabkan dari pengaturan tentang perempuan semata-mata dilihat dari sector kodrat biologis, kepercayaan, kebudayaan. Pada pasal 27 UUDNRI Tahun 1945 telah menegaskan mengenai kedudukan segala warga negara didalam hukum serta pemerintahan dan wajib menjunjung hukum serta pemerintahan tanpa terkecuali. Pasal tersebut mencerminkan bahwa kedudukan semua warga negara di dalam hukum dan pemerintahan tanpa adanya diskriminasi dari pihak manapun. Kondisi jurnalis perempuan saat melaksanakan tugas dilapangan tidak terhindarkan dari kekerasan, stereotype serta subordinasi. Mengenai konsep gender yang digunakan dalam mengidentifikasi perbedaan untuk laki-laki dan perempuan. Dalam hal perbedaan gender terdapat dua hal yang dipahami antara lain kesetaraan gender serta keadilan terkait status yang sama dan ketidak adilan serta diskiriminasi yang berkaitan dengan perbedaan dari segi peran serta kedudukan antara perempuan dan laki-laki sehingga menimbulkan kebijakan-kebijakan yang berdampak menimbulkan ketidakadilan dalam struktur masyarakat. ${ }^{5}$ Dalam konvensi Internasional yaitu International Convention on Elimination of All Forms of Discrimination

${ }^{4}$ Karen Ross and Cynthia Carter, "Women and News: A Long and Winding Road," Media, Culture \& Society 33, no. 8 (2011): 1148-65.

${ }^{5}$ Ilyas Lampe, "Perempuan Dalam Pengelolaan Surat Kabar Di Sulawesi Tengah (Studi Posisi Dan Peran Perempuan Dalam Media Cetak)," Academica 2, no. 1 (2010). 
Againts Woman merupakan kesepakatan hak asasi internasional khusus mengatur mengenai hak-hak perempuan dan Indonesia menyampaikan upaya pemerintah khususnya pada program peningkatan kesetaraan gender serta anti diskriminasi terhadap perempuan Indonesia. Konvensi ini kemudia diratifikasi kedalam UndangUndang No 7 Tahun 1984 tentang ratifikasi konvensi PBB mengenai penghapusan segala bentuk diskriminasi terhadap perempuan yang disingkat menjadi konvensi wanita telah secara tegas mengatur mengenai hak-hak perempuan khususnya penghapusan diskriminasi dalam bentuk apapun.

Aturan dalam UU ketenagakerjaan juga telah menekankan pada upah layak yang patut diberikan kepada jurnalis perempuan sehingga tidak terjadinya tindak kekerasan serta diskriminasi antara lain mengenai asuransi keselamatan saat bekerja, jaminan kesehatan maupun social, hak cuti, tunjangan, pelatihan keterampilan berkala, tidak memperkerjakan jika membahayakan keselamatan pada kandungannya, memberikan reward untuk prestasinya. Tidak hanya aturan dalam hal diatas, tertuang juga dalam Deklarasi Universal terhadap hak-hak perempuan dan konvensi anti diskriminasi kepada perempuan yang isinya adalah larangan bagi setiap individu ataupun institusi dalam melakukan tindakan diskriminasi kepada perempuan.

Seperti penelitian sebelumnya Yolanda Stellarosa dan Martha Warta Silaban ${ }^{6}$ dalam penulisan yang berjudul Perempuan, media, dan profesi jurnalis dengan metode penelitian yang digunakan adalah kualitati deskriptif yang memberikan kesimpulan bahwa jurnalis laki-laki dominan daripada jurnalis perempuan dalam sector media yang membuktikan masih adanya diskriminasi terhadap perempuan terutama dalam sector publik, kemudian Khusnul Khotimah ${ }^{7}$ dalam penelitian yang berjudul diskriminasi gender terhadap perempuan dalam sector pekerjaan memberikan kesimpulan bahwa akibat modernitas, perempuan termarginalisasi khususnya pada sector pekerjaan dalam hal mendapatkan upah rendah karena melakukan pekerjaan pada sector informal. Faktor subordinat dalam social budaya juga sangat mempengaruhi diskriminasi terhadap perempuan. Berbeda dengan pembahasan yang akan diuraikan oleh penulis yaitu representasi terhadap jurnalis perempuan dilihat dari perspektif gender dan strategi perlindungan hukum terhadap jurnalis perempuan yang akan menggali lebih dalam mengenai ketimpangan pada peraturan perundangundangan khususnya kesetaraan gender.

Berdasar pada uraian diatas muncul isu yang mendasar terkait dengan permasalahan apa yang sebenarnya dihadapi jurnalis perempuan serta strategi perubahan dalam memberikan perlindungan hukum terkait jurnalis perempuan. Berdasarkan uraian latar belakang diatas, maka penulis sangat tertarik dalam membahas penelitian mengenai urgensi perlindungan hukum terhadap jurnalis perempuan berspektif kesetaraaan gender.

\section{Metode Penelitian}

Mengenai jenis penelitian yang digunakan oleh penulis adalah tipe penelitian hukum normative yaitu analisis kepustakaan berdasar pada bahan hukum yang digunakan

${ }^{6}$ Yolanda Stellarosa and Martha Warta Silaban, "Perempuan, Media Dan Profesi Jurnalis," Jurnal Ilmu Komunikasi 16, no. 3 (2018): 283-94.

${ }^{7}$ Khusnul Khotimah, "Diskriminasi Gender Terhadap Perempuan Dalam Sektor Pekerjaan," Yinyang: Jurnal Studi Islam Gender Dan Anak 4, no. 1 (2009): 158-80. 
baik primer maupun sekunder, membahas doktrin-doktrin atau asas dalam ilmu hukum. ${ }^{8}$ Dalam metode pendekatan masalah yang diguakan dalam penelitian ini adalah pendekatan perundang-undangan dan pendekatan konseptual dan pendekatan filosofis. Dalam pembahasan mengenai isu-isu diatas menggunakan sumber bahan hukum. Sumber bahan hukum yang digunakan penulis adalah sumber bahan hukum primer dan sekunder. Sumber bahan hukum primer merupakan sumber bahan hukum yang mempunyai kekuatan mengikat dalam penelitian. Sedangkan sumber bahan hukum sekunder merupakan bahan-bahan hukum yang dapat diperoleh dari pengkajian kepustaaan. Dalam hal pengumpulan bahan hukum penulis baik bahan hukum primer maupun sekunder penulis menggunakan metode pengumpulan bahan hukum lalu dikelompokkan, dicatat, dikutip, diringkas, diulas sesuai dengan kebutuhan pendekatan kualitatif. Analisis bahan hukum yang digunakan penulis yaitu menggunakan teknik bersifat sistematis dengan disajikan secara deskriptif analitis yang mendeskripsikan terlebih dahulu bahan hukum secara sistematis kemudian menganalisis melalui teknik analisis menggunakan argumentasi serta intepretasi pada konsep-konsep hukum yang terkait.

\section{Hasil dan Pembahasan}

Secara etimologis memberikan pengertian perempuan dari kata empu yang memili arti tuan, seseorang yang paling berkuasa. ${ }^{9}$ Dilihat dari faktor biologis bahwa perempuan dapat dilihat dari segi fisik dan psikis. Pasal 1 dalam deklarasi universal yang mengatur tentang HAM yaitu tiap orang terlahir secara merdeka, bermartabat, mempunyai kesamaan hak, dikaruniai dengan akal serta hati nurani sehingga dapat bersosialisasi dengan lainnya. Sedangkan pasal 1 konvensi penghapusan diskriminasi terhadap perempuan memberikan pengertian bahwa diskriminasi tersebut merupakan pengucilan, perbedaan atau pembatasan yang berdasar atas jenis kelamin yang sangat berpengaruh besar dengan tujuan mengurangi penggunaan hak asasi manusia serta kebebasan pokoknya disegala bidang. Konvensi hak asasi manusia secara internasional mengenai pasal-pasal yang menghapuskan semua bentuk diskriminasi bagi perempuan antara lain:

a. Pengutukan segala bentuk diskriminasi, upaya penegakan mengenai persamaan hak dan kewajiban perempuan dalam UU.

b. Kewajiban bagi Negara dalam hal pembentukan peraturan-peraturan mengenai penghapusan diskriminasi pada perempuan baik dalam bidang politik maupun kehidupan bermasyarakat.

c. Kewajiban tiap Negara yang tergabung dalam pembentukan aturan mengenai penghapusan diskriminasi bagi perempuan dalam segala bisang (pendidikan, kesehatan, mendapatkan pekerjaan serta social ekonomi.

d. Kewajiban tiap Negara dalam hal pemberian persamaan hak bagi perempuan di muka hukum serta penghapusan diskriminasi dalam hal perkawinan maupun dalam hal hubungan kekeluargaan.

e. Pembentukan panitia internasional dalam melakukan penilaian terhadap kemajuan pada implementasi.

f. Setiap negara berhak dalam mengajukan keberatan-keberatan.

${ }^{8}$ AZainuddin Ali, "Metode Penelitian Hukum," 2016. h.24

${ }^{9}$ Mansour Fakih, Analisis Gender Dan Transformasi Sosial (Insist Press, 2008). ,h.135. 
Konstruksi secara ideologis mengenai peran serta kemampuan setiap perempuan dapat memberikan pengaruh dalam hal memperoleh segala kesempatan-kesempatan baik secara individu ataupun kelembagaan. ${ }^{10}$ Gender diartikan sifat yang terdapat dalam kaum laki-laki ataupun perempuan sehingga terkonstruksikan baik social maupun cultural. Dari dahulu hingga sekarang masih terdapat banyak tindakan diskriminasi yang terjadi pada perempuan seperti penganiayaan, pelecehan, perkosaan dan lainnya. Rasa keadilan tidak dapat diterapkan serta diberlakukan secara umum dan tiap individu mepunyai perasaan subjektif dalam membedakan adil dan tak adil. Secara resmi pemerintah di Indonesia telah menganut asas persamaan yang telah diatur dalam pasal 27 UUDNRI tahun 1945 yang menyatakan tiap warganegara serta kedudukannya baik di depan hukum maupun pemerintah tanpa terkecuali. Sehingga memberikan control bagi laki-laki dan perempuan baik mengenai akses maupun partisipasi di segala bidang baik bidang social, politik maupun ekonomi.

Terdapat 3 prinsip dalam International Convention on Elimination of All Forms of Discrimination Againts Woman yang diratifikasi kedalam Undang-Undang No 7 Tahun 1984 antara lain:

- Dalam hal persamaan substantive yang mewajibkan pada negara dalam menjamin persamaan antara perempuan dan laki-laki baik berupa Per-UU ataupun lainnya yang menitikberatkan pada akses serta penikmatan manfaat yang sama sarana maupun prasarana.

- Prinsip Non diskriminasi yaitu dalam mencapai persamaan antara perempuan dan laki-laki haruslahmenghapus segala bentuk diskriminasi.

- Prinsip kewajiban negara yaitu manjamin hak-hak perempuan melalui langkah-langkah dalam menciptakan kondisi kondusif dalam peningkatan kemampuan dalam mendapatkan peluang dan kesempatan khususnya sektor publik.

Pokok-pokok dalam International Convention on Elimination of All Forms of Discrimination Againts Woman yang diratifikasi kedalam Undang-Undang Nomor 7 tahun 1984 juga diatur pula dalam undang-undang yang lain tanpa adanya tindakan diskriminatif khususnya terhadap perempuan.

Intruksi Presiden No.9 tahun 2000 mengenai pengarustamaan gender dalam pembangunan nasional yang mengintruksikan kepada seluruh pemerintah baik pusat maupun daerah dalam pengarusutamaan gender demi terselenggaranya segala aspek pembangunan nasional.

Gender merupakan suatu konsep dibentuk berdasar pada nilai social budaya masyarakat, maka dapat dikatakan gender bersifat dapat berubah-ubah sesuai dengan perkembangan jaman baik kemajuan ilmu pengetahuan maupun teknologi dan sebagainya. ${ }^{11}$

10 Louisa Yesami Krisnalita, "Perempuan, Ham Dan Permasalahannya Di Indonesia," Binamulia Hukum 7, no. 1 (2018): 71-81.

${ }^{11} \mathrm{Ni}$ Nyoman Sukerti, I Gusti Ayu Agung Ariani, and I Gusti Agung Ayu Ari Krisnawati, "IMPLIKASI IDEOLOGI GENDER DALAM HUKUM ADAT BALI (STUDI DI KOTA DENPASAR)," Jurnal Magister Hukum Udayana (Udayana Master Law Journal) 5, no. 4 (2016): 805-17. 
Wood berpendapat jika media menyajikan perempuan dan laki-laki secara stereotipikal yang memberikan batasan pada persepsi mengenai kemungkinan manusia. Ia menunjukan bahwa dari penggambaran tersebut menjadikan media merefleksikan serta mendorong pengembangan relasi terhadap laiki-laki dan perempuan dianggap patut dalam konteks tradisional antara lain:12

a. Pandangan bahwa perempuan sangat ketergantungan sedangkan laki-laki adalah insan yang mandiri.

b. Pandangan bahwa perempuan tidak mempunyai kompeten sedangkan lakilaki mempunyai otoritas

c. Pandangan bahwa perempuan bertugas dalam mengasuh sedangkan lakilaki bertugas untuk mencari nafkah.

d. Pandangan bahwa perempuan sebagai korban ataupun objek seksual sedangkan laki-laki adalah aggressor.

\subsection{Representasi Terhadap Jurnalis Perempuan Dari Perspektif Gender Dalam Media Massa}

Pada persektif gender yang merupakan suatu perwujudan terhadap kesadaran kritis mengenai pengelolaan serta pekerja media perlu dijalankan dengan baik oleh laki-laki ataupun perempuan karena dapat dikatakan bahwa kesadaran mengenai gender tak semata-mata terkait jenis seksualitas tiap individu. Khususnya pada dunia jurnalistik dikatakan wilayah paling kentara yang memberikan posisi perempuan pada kontek dikotomi sedangkan laki-laki sebagai rival. Sosok perempuan tidak dapat dilepaskan dari semangat feminisme yang dimulai pada persepsi mengenai penyimbanganpenyimpangan yang ada di masyarakat sehingga posisi perempuan berbanding dengan posisi laki-laki.

Faktanya, persoalan gender yang sebenarnya tersimpan dalam suatu organisasi yang berkaitan dengan media. Merujuk pada masyarakat patriarki, ideology dan asumsi mengenai cultural tersebut bertitik tolak dari sudut pandang, kepentingankepentingan serta nilai yang ada pada laki-laki. ${ }^{13}$ Perwujudan mengenai kesetaraan antara perempuan dan laki-laki tak hanya dilihat pada pengambilan penafsiranperafsiran sehingga terciptanya makna memungkinkan perempuan turut menjelaskan kembali perannya. Perspektif gender dalam perwujudannya perlu dijalankan dengan baik oleh perempuan mauppun laki-laki mengenai berbagai aspek.

Permasalahan mengenai gender yang ada pada media kurang lebih menyangkut pada posisi marginalisasi dan subordinasi bagi perempuan diberbagai bidang antara lain sedikitnya keterlibatan bagi perempuan pada aktivitas jurnalisme, legitimasi mengenai bias gender, kepentingan ekonomi dan politik yang mendominasi, regulasi pada media yang tidak sensitive mengenai gender serta kesenjangan antara jurnalisme konvenssional serta sensitive gender.

Merujuk dari salah satu teori yang digunakan penulis yaitu Feminism lebih khususnya feminism liberal yang sebagai dasar dari pemikiran bahwa semua manusia dalam hal

${ }^{12}$ Kathryn Greene, "Disclosure of Chronic Illness Varies by Topic and Target: The Role of Stigma and Boundaries in Willingness to Disclose," Balancing the Secrets of Private Disclosures, 2000, 123-35.

${ }^{13}$ Klenin Emily, "The Poetics of Afanasy Fet," Bausteine Zur Slavischen Philologie Und Kulturgeschichte (39), 2002. 
ini perempuan maupun laki-laki merupakan insane yang seimbang serta serasi. Feminism marxis-sosialis memberikan pengertian dari ketimpangan dalam perspektif gender yang terdapat didalam kehidupan masyarakat yang merupakan penerapan sistem kapitalis dalam mendukung terjadinya tenaga kerja yang tidak memberikan upah bagi perempuan pada kehidupan berumah tangga serta Feminism Radikal yang pada itinya memberikan tuntutan adanya persamaan hak bagi laki-laki dan perempuan dan juga menuntut persamaan dalam hal seksual. Dalam aturan pers yaitu pasal 8 UU No 40 tahun 1999 menyatakan bahwa saat wartawan menjalankan profesi atau tugasnya maka wartawan tersebut mendapatkan perlindungan hukum. Sedangkan pasal 2 kode etik jurnalistik menyatakan bahwa wartawan di Indonesia menggunakan langkah-langkah professional pada saat pelaksanaan tugasnya. Kenyataan yang terjadi mengenai eksploitasi perempuan dalam sebuah kepentingan rating maupun tiras padahal secara umum peran media massa memberikan kontribusi besar pada proses kontruksi realitas individu.

Pemahaman mengenai isu yang mengandung gender dan media yang saling berkaitan adalah pada partisipasi terhadap perempuan saat mengambil keputusan dan kebebasan berekspresi di media dan representasi ataupun penggambaran berkenaan dengan perempuan serta hubungannya antara gender dan media. Kekerasan terhadap perempuan dalam media tidak saja dilihat pada tindakan kekerasan yang terjadi melainkan kekerasan yang sering dialami oleh sebagain besar jurnalis perempuan yang menjadi pekerja pada media.

Penelitian yang dilakukan oleh Global media monitoring, pada saat ini jumlah pekerja media khususnya perempuan masih rendah yaitu mencapai 36\%. Dari jumlah tersebut kebanyakan tidak dapat mengambil sebuah keputusan. Kekerasan yang terjadi pada jurnalis perempuan mengenai banyaknya halangan yang menjadi penyebab jurnalis perempuan mengalami diskriminasi pada pekerjaanya. Masih adanya jurnalis perempuan yang menerima tindak kekerasan yang berupa subordinasi sehingga dapat dikatakan bahwa yang menjadi rintangan pada peningkatan karir seorang jurnalis perempuan disebabkan adanya tindakan subordinasi dan stereotif yang terjadi para perempuan. Adapun hal yang terjadi antara lain ketimpangan pada gaji, kurannya akses yang berkaitan dengan pekerjaanya seperti training, pelecehan seksual, ketidakadilan, kurangnya fasilitas serta kurangnya penghargaan yang diberikan kepada jurnalis perempuan.

Menurut Soemardoyo, jurnalis perempuan sangat sadar pada saat mendahulukan kepentingan bagi keluarganya sangat beresiko bagi ancaman kesuksesan baaaik karir maupun pendapatannya dan resiko yang dihadapi juga yaitu kehilangan keluarga pada saat berada di titik nadir. ${ }^{14}$

Munculnnya genderisasi mengenai tugas antara perempuan dan laki-laki sebagai pekerja pada media merupakan contoh diskriminasi sehingga berujung mengenai kekerasan seperti dalam ranah publik, seorang perempuan tidak dapat terpisahkan dari feminisme yang berpengaruh pada kinerjanya. Adanya ketidaksetaraan gender merupakan suatu bentuk ghetoisme yang memberikan tempat bagi perempuan dalam mengelola isu-isu lunak sementara yang menjadi hard issue menjadi tempat bagi laki-

14 Prio Soeman Doyok, "Wacana Gender Dan Layar Televisi (Study Perempuan Dalam Pemberitaan Televisi Swasta," LKIS, Yogjakarta, 1999. h.136. 
laki selain itu, evalusi mengenai kinerja jurnalis perempuan kerap diwarnai dengan hal-hal tidak professional.

Dalam anggapan stereotype bahwa perempuan merupakan pribadi yang emosional yang mengakibatkan perempuan berada pada posisi yang tidak penting. Stereotype merupakan suatu penandaan suatu kelompok yang dapat mengakibatkan stigma dan tentu akan memberikan kerugian serta ketidakadilan contohnya seperti pandangan pada jenis kelamin sehingga dapat menimbulkan ketidakadilan terhadap jenis kelamin tersebut. Hal yang dihadapi oleh jurnalis perempuan dalam perannya sebagai tenaga kerja perempuan dapat dilihat dari membagi waktunya antara mengurus keluarga dan menyelesaikan pekerjaannya. Kontrol social dalam suatu pekerjaan yang dilakukan oleh perempuan menjadikan laki-laki mendapatkan keuntungan material dari konsep budaya patriaki tersebut sehingga menimbulkan basis keuntungan laki-laki dari budaya tersebut.

\subsection{Strategi Perlindungan Hukum Terhadap Jurnalis Perempuan Dalam Perspektif Gender}

Negara Indonesia merupakan negara hukum sebagaimana telah dituangkan di Pasal 1 ayat 3 UUDNRI yang memiliki arti segala penyelenggaraan terkait negara harus sesuai dengan hukum dan berlaku untuk segala aspek kehidupan sehingga akan menciptakan tujuan hukum yang dicitakan. ${ }^{15}$

Menciptakan suatu landasan hukum dalam menjamin kebebasan bagi pers diperlukan banyak strategi terkait menumbuhkan segala bentuk dukungan diberbagai pihak. Di Indonesia, regulasi mengenai pemjaminan dalam memberikan kebebasan dalam berpendapat perlu untuk diamandemen agar lebih memberikan jaminan dalam hal bebebasan pers yang nantinya diperlukan untuk secara tegas larangan bagi pemerintahan dalam membuat regulasi yang dapat member batasan-batasan daam kebebasan per situ sendiri maupun dalam hal kemerdekaan dalam berpendapat. ${ }^{16}$

Tidak memadainya fungsi hukum untuk sarana dalam mencapai perubahan khususnya dalam hal keadilan sehingga masih menimbulkan kritik dan kegelisahan. ${ }^{17}$

Ditinjau dari regulasi luar negeri khususnya Negara Amerika yang memberikan penegasan dalam hal freedom of speech yaitu kongres tidak dijinkan membuat regulasi/undang-undang yang nantinya dapat mengurangi kebebasan pers, kebebaan dalam berbicara ataupun mengurangi hak-hak rakya dalam berkumpul serta dalam hal pengajuan petisi kepada pemerintah yang bertujuan dalam perbaikan penderitaan.

Upaya penanggulangan dari masyarakat adalah adanya upaya yang dilaksanakan melalui pembelajaran sejak dini melalui law education yang bertujuan dalam hal saking menghormati serta dalam melindungi hak-hak asasi manusia. Perubahan akan hal

${ }^{15}$ Ni Luh Made Dwi Pusparini, A A Sagung Laksmi Dewi, and I Made Minggu Widyantara, "Urgensi Saksi Pelaku Yang Bekerjasama (Justice Collaborator) Dalam Tindak Pidana Korupsi," Jurnal Interpretasi Hukum 1, no. 1 (2020): 179-85.

${ }^{16}$ Malang Harijanto, "PERLINDUNGAN HUKUM TERHADAP WARTAWAN DALAM PELIPUTAN BERITA-BERITA PEMERINTAHAN DAN MASYARAKAT," Jurnal Hukum Unsrat 2, no. 1 (2014): 1-15.

17 Gde Made Swardhana, "Pergulatan Hukum Positivistik Menuju Paradigma Hukum Progresif," Masalah-Masalah Hukum 39, no. 4 (2010): 378-84. 
yang berkaitan dengan ideology gender akan ikut bersamaan dengan kehidupan atas perkembangan masyarakatnya sehingga peran mengenai status antara laki-laki dan perempuan akan memberikan pengaruh terhadap nilai, sikap ataupun perilaku masayarakat itu sendiri. Hal tersebut telah jelas akan memberi pengaruh yang cukup besar dalam seluruh bidang kehidupan masyarakat. ${ }^{18}$

Permasalahan perempuan dalam hal ketenagakerjaan sangat terkait terhadap kemakmuran serta kelangsungan hidup yang berhak atas pekerjaan serta hidup yang layak yang dijamin oleh UUDNRI, hal ini tercermin dalam UU ketenagakerjaan No 13 Tahun 2003yang juga menjadi solusi memberi perlindungan terhadap pekerja maupun orang yang mempekerjakannya berupa hak serta kewajiban yang nantinya salah satu tujuannya untuk adanya jaminan terhadap hak dasar bagi pekerja serta adanya jaminan terhadap kesempatan dan tidak adanya diskriminasi. Munculnya UU Ketenagakerjaan memberikan esensi demi kesejahteraan pekerja dalam mewujudkan kemajuan di dunia kerja seperti salah satu nya adalah kemerdekaan terhadap pers. Profesi jurnalistik menuntut tanggung jawab serta kesadaran yang tinggi dalam menjalankan profesi tersebut yang nantinya tanggung jawab pers merupakan tugas serta tanggung jawab dalam menjalankan fungsi dalam memberikan informasi di media.

Dalam pencegahan ketimpangan gender yang berlarut-larut mengenai perempuan khususnya terhadap jurnalis perempuan maka perlu adanya rekonstruksi hukum mengingat perempuan merupakan warga negara dalam pembangunan sumber daya perempuan tentu mempunyai kedudukan sama terhadap laki-laki dalam hal kedudukannya, hak-haknya serta kewajiban-kewajibannya sehingga memperoleh kesempatan yang sama dalam berbagai bidang.

Secara Internasional ataupun secara nasional menyatakan bahwa hukum serta peraturan per-UU telah mengakui mengenai prinsip kesamaan mengenai hak serta kewajiban antara perempuan maupun laki-laki, akan tetapi dilihat dari implementasi dalam penyelenggaraan masih memunculkan ketidakadilan. Budaya Patriarki adalah salah satu penyebab yang berkembang pada masyarakat adat di Indonesia yang dimana laki-laki sebagai pemegang kekuasaan sehingga dapat mendegradasi peran seorang perempuan. ${ }^{19}$

Berpedoman dalam pengarustamaan gender sesuai Intruksi Presiden No 9 tahun 2000 membuktikan jika pemerintah serius dalam hal melakukan upaya-upaya menghilangkan segala bentuk diskriminasi serta aturan tersebut sebagai dasar terhadap segala hal yang berspektif gender tanpa terkecuali sehingga apabila tidak sejalan maka aturan mengenai hal tersebut harus diganti. Selain itu, Peraturan Presiden No 65 tahun 2005 dibentuk untuk pencegahan serta menanggulangi segala tindak kekerasan kepada perempuan.

Terkait bidang struktur pada penegak hukum saat perempuan berada pada posisi sebagai korban maupun saksi harus mendapatkan kondisi aman agar bias memberikan

${ }^{18}$ I Ketut Sudantra and I Gusti Ngurah Dharma Laksana, "PENGARUH IDEOLOGI GENDER TERHADAP PERKEMBANGAN HAK WARIS PEREMPUAN BALI," Jurnal Magister Hukum Udayana (Udayana Master Law Journal) 5, no. 4 (2016): 818-32.

${ }^{19}$ Dede Kania, "Hak Asasi Perempuan Dalam Peraturan Perundang-Undangan Di Indonesia: The Rights of Women in Indonesian Laws and Regulations," Jurnal Konstitusi 12, no. 4 (2015): 716-34. 
keterangan-keterangan tanpa adanya unsur tekanan. Saat ini para penegak hukum masih belum pengutamaan kepentingan korban sehingga hal ini akan menghilangan hak-hak korbandalam mendapatkan perlindungan saat menjadi korban terutama korban kekerasan. ${ }^{20}$

Dalam budaya hukum perlu ditegakkan kepedulian masyarakat yang harus ditingkatkan mengenai kepekaan akan isu kekerasan terutama kekerasan pada perempuan sehingga penting untuk terlaksananya mengubah budaya masyarakat yang masih diskriminatif dan juga sangat perlu adanya penegakan hukum dengan sensitive gender dengan cara merefleksikan pengakuan pada hak perempuan. Cara dalam mengakhiri system ketidakadilan perlu dilakukan beberapa cara antara lain melakukan dekonstruksi idiologi dalam melawan pengaruh yang merendahkan martabat perempuan serta melawan asumsi mengenai tidak adanya partisipasi perempuan dalam pembangunan. ${ }^{21}$

Rekonstruksi hukum harus dilakukan dalam melawan tindakan yang merendahkan martabat seorang perempuan dan adanya rekonstruksi hukum sebagai dasar untuk perempuan dalam melawan ketidak adilan atau diskriminasi baik lingkup nasional maupun internasional.

\section{Kesimpulan}

Perspektif gender dalam perwujudannya perlu dijalankan dengan baik oleh perempuan mauppun laki-laki mengenai berbagai aspek. Permasalahan mengenai gender yang ada pada media kurang lebih menyangkut pada posisi marginalisasi dan subordinasi bagi perempuan. Kenyataan yang terjadi mengenai eksploitasi perempuan dalam sebuah kepentingan rating maupun tiras padahal secara umum peran media massa memberikan kontribusi besar pada proses kontruksi realitas individu. Pemahaman mengenai isu yang mengandung gender dan media yang saling berkaitan adalah pada partisipasi terhadap perempuan saat mengambil keputusan dan kebebasan berekspresi di media dan representasi ataupun penggambaran berkenaan dengan perempuan serta hubungannya antara gender dan media. Secara Internasional ataupun secara nasional menyatakan bahwa hukum serta peraturan per-UU telah mengakui mengenai prinsip kesamaan mengenai hak serta kewajiban antara perempuan maupun laki-laki. Dalam pencegahan ketimpangan gender yang berlarutlarut mengenai perempuan khususnya terhadap jurnalis perempuan maka perlu adanya rekonstruksi hukum mengingat perempuan merupakan warga negara dalam pembangunan sumber daya perempuan tentu mempunyai kedudukan sama terhadap laki-laki dalam hal kedudukannya, hak-haknya serta kewajiban-kewajibannya sehingga memperoleh kesempatan yang sama dalam berbagai bidang. Dalam budaya hukum perlu ditegakkan kepedulian masyarakat yang harus ditingkatkan mengenai kepekaan akan isu kekerasan terutama kekerasan pada perempuan sehingga penting untuk terlaksananya mengubah budaya masyarakat yang masih diskriminatif dan juga sangat perlu adanya penegakan hukum dengan sensitive gender dengan cara merefleksikan pengakuan pada hak perempuan. Cara dalam mengakhiri system ketidakadilan perlu dilakukan beberapa cara antara lain melakukan dekonstruksi

20 Ibid., h.16

${ }^{21}$ Mohd Anuar Ramli, “Analisis Gender Dalam Hukum Islam,” Jurnal Fiqh 9 (2012): 137-62. h. 152. 
ideologi dalam melawan pengaruh yang merendahkan martabat perempuan serta melawan asumsi mengenai tidak adanya partisipasi perempuan dalam pembangunan.

\section{Daftar Pustaka}

Ali, Zainuddin. "Metode Penelitian Hukum," 2016.

Anom, Erman. “Wajah Pers Indonesia 1999-2011." Jurnal Komunikasi: Malaysian Journal of Communication 27, no. 1 (2011).

Byerly, Carolyn M. "Behind the Scenes of Women's Broadcast Ownership." The Howard Journal of Communications 22, no. 1 (2011): 24-42.

Emily, Klenin. "The Poetics of Afanasy Fet." Bausteine Zur Slavischen Philologie Und Kulturgeschichte (39), 2002.

Fakih, Mansour. Analisis Gender Dan Transformasi Sosial. Insist Press, 2008.

Greene, Kathryn. "Disclosure of Chronic Illness Varies by Topic and Target: The Role of Stigma and Boundaries in Willingness to Disclose." Balancing the Secrets of Private Disclosures, 2000, 123-35.

Harijanto, Malang. "PERLINDUNGAN HUKUM TERHADAP WARTAWAN DALAM PELIPUTAN BERITA-BERITA PEMERINTAHAN DAN MASYARAKAT." Jurnal Hukum Unsrat 2, no. 1 (2014): 1-15.

Kania, Dede. "Hak Asasi Perempuan Dalam Peraturan Perundang-Undangan Di Indonesia: The Rights of Women in Indonesian Laws and Regulations." Jurnal Konstitusi 12, no. 4 (2015): 716-34.

Khotimah, Khusnul. "Diskriminasi Gender Terhadap Perempuan Dalam Sektor Pekerjaan." Yinyang: Jurnal Studi Islam Gender Dan Anak 4, no. 1 (2009): 158-80.

Krisnalita, Louisa Yesami. "Perempuan, Ham Dan Permasalahannya Di Indonesia." Binamulia Hukum 7, no. 1 (2018): 71-81.

Lampe, Ilyas. "Perempuan Dalam Pengelolaan Surat Kabar Di Sulawesi Tengah (Studi Posisi Dan Peran Perempuan Dalam Media Cetak)." Academica 2, no. 1 (2010).

Neill, Sam. "Books and Marshall McLuhan." The Library Quarterly 41, no. 4 (1971): 31119.

Pusparini, Ni Luh Made Dwi, A A Sagung Laksmi Dewi, and I Made Minggu Widyantara. “Urgensi Saksi Pelaku Yang Bekerjasama (Justice Collaborator) Dalam Tindak Pidana Korupsi." Jurnal Interpretasi Hukum 1, no. 1 (2020): 17985.

Ramli, Mohd Anuar. “Analisis Gender Dalam Hukum Islam.” Jurnal Figh 9 (2012): 13762.

Ross, Karen, and Cynthia Carter. "Women and News: A Long and Winding Road." Media, Culture E Society 33, no. 8 (2011): 1148-65.

Soeman Doyok, Prio. "Wacana Gender Dan Layar Televisi (Study Perempuan Dalam Pemberitaan Televisi Swasta." LKIS, Yogjakarta, 1999.

Stellarosa, Yolanda, and Martha Warta Silaban. "Perempuan, Media Dan Profesi Jurnalis." Jurnal Ilmu Komunikasi 16, no. 3 (2018): 283-94.

Sudantra, I Ketut, and I Gusti Ngurah Dharma Laksana. "PENGARUH IDEOLOGI GENDER TERHADAP PERKEMBANGAN HAK WARIS PEREMPUAN BALI." Jurnal Magister Hukum Udayana (Udayana Master Law Journal) 5, no. 4 (2016): 818-32.

Sukerti, Ni Nyoman, I Gusti Ayu Agung Ariani, and I Gusti Agung Ayu Ari Krisnawati. "IMPLIKASI IDEOLOGI GENDER DALAM HUKUM ADAT BALI (STUDI DI KOTA DENPASAR)." Jurnal Magister Hukum Udayana (Udayana 
Master Law Journal) 5, no. 4 (2016): 805-17.

Swardhana, Gde Made. "Pergulatan Hukum Positivistik Menuju Paradigma Hukum Progresif." Masalah-Masalah Hukum 39, no. 4 (2010): 378-84.

\section{Peraturan Perundang-Undangan}

Undang-Undang Dasar Negara Kesatuan Republik Indonesia Tahun 1945

Undang-Undang Nomor 7 Tahun 1984 tentang Ratifikasi Konvensi PBB tentang Penghapusan Segala Bentuk Diskriminasi terhadap Perempuan.

Undang-Undang Nomor 39 Tahun 1999 tentang Hak Asasi Manusia Undang-Undang Nomor 40 Tahun 1999 tentang Pers

Instruksi Presiden Nomor 9 Tahun 2000 tentang Pengarustamaan Gender dalam Pembangunan Nasional.

Undang-Undang Nomor 13 Tahun 2003 tentang Ketenagakerjaan

Peraturan Presiden Nomor 65 Tahun 2005 tentang Komisi Nasional Anti Kekerasan Terhadap Perempuan.

Undang-Undang Nomor 11 Tahun 2008 tentang Informasi dan Transaksi Elektronik 